of successful transplantation ${ }^{8}$ or by dialysis using a water purification system.

We conclude that aluminium contamination of the water used for dialysis is the probable cause of dialysis encephalopathy. The resulting aluminium intoxication is not confined to the nervous system but is almost certainly a factor in causing bone disease and possibly also in aggravating anaemia. We reiterate the advice of others ${ }^{4}$ that all patients who dialyse in areas with a high concentration of aluminium in the water should use some form of water purification system, though this will not necessarily protect patients who have already accumulated large amounts of aluminium. At present the use of deionisers or reverse-osmosis apparatus may be the most effective method of extracting aluminium from the water, but more-specific techniques may be devised if it can be confirmed that aluminium is the only potential toxin in the supply to an area.

We thank the water department of Strathclyde regional council for their invaluable co-operation and for analysing the water supplies; Dr J M Ottaway, of the department of pure and applied chemistry,
University of Strathclyde, Glasgow, for his advice on the serum aluminium methodology; Dr Heather Dick and Dr J W Dobbie for providing blood samples; and Professor A C Kennedy for his guidance and for financial support to SS.

\section{References}

${ }^{1}$ Alfrey, A C, Le Gendre, G R, and Kaehny, W D, New England fournal of Medicine, 1976, 294, 184

${ }^{2}$ Flendrig, J A, Kruis, H, and Das, H A, Lancet, 1976, 1, 1235.

3 Ward, M K, personal communication.

4 Platts, M M, Goode, G C, and Hislop, J S, British Medical fournal, 1977, 2, 657.

${ }^{5}$ Alfrey, A C, et al, Transactions. American Society for Artificial Internal Organs, 1972, 18, 257.

${ }^{6}$ Pierides, A M, Ward, M K, and Kerr, D N S, Lancet, 1976, 1, 1234.

${ }^{7}$ Elliott, $\mathrm{H} \mathrm{L}$, et al, unpublished data.

8 Sullivan, P A, Murnaghan, D J, and Callaghan, N, British Medical fournal, $1977,2,740$.

\title{
Serum ionised calcium concentration: measurement versus calculation
}

\author{
S C CONCEICAO, DORIS WEIGHTMAN, P A SMITH, J LUNO, M K WARD, D N S KERR
}

British Medical fournal, 1978, 1, 1103-1105

\section{Summary and conclusions}

Four hundred and eighteen measurements of serum ionised calcium, total calcium, and protein concentrations were made from 47 normal volunteers, 104 patients with chronic renal failure (33 being treated conservative$1 y$ and 71 with regular haemodialysis), and 83 renal transplant recipients. The serum ionised calcium concentration was measured with an Orion SS-20 meter and calculated from the total serum calcium and protein concentrations by using three formulae and a nomogram. In the normal subjects and patients undergoing regular haemodialysis, whose serum calcium concentrations were in or near the normal range, three of the calculations gave results similar to those obtained by direct measurement. In patients with conservatively treated chronic renal failure and those who had received renal transplants, however, there was poor agreement between the methods. When patients with hypercalcaemia and hypocalcaemia from all the groups were considered separately there was again poor agreement between calculated and measured concentrations of serum ionised calcium. Of the patients whose measured concentrations of serum ionised calcium were high, $69-76 \%$ were classified as normal by the four indirect methods.

\footnotetext{
Royal Victoria Infirmary, University of Newcastle upon Tyne, Newcastle upon Tyne NE1 4LP

$S C$ CONCEICAO, $\mathrm{MD}$, senior research associate in medicine

DORIS WEIGHTMAN, assistant in medical statistics

P A SMITH, BSC, PHD, top-grade biochemist

I LUNO, MD, senior research associate in medicine (present address: Servicio de Nefrologia, CSP "Francisco Franco," c o Doctor Esquerdo 46, Madrid, Spain

$M \mathrm{~K}$ WARD, MB, MRCP, lecturer in medicine (now consultant physician) D N S KERR, MSC, FRCP, professor of medicine
}

We conclude that calculation of the serum ionised calcium concentrations is not an adequate substitute for direct measurement.

\section{Introduction}

About half the calcium in serum is bound to protein or complexed. It is the other half, ionised and biologically active, that interests the clinician, but for the past 40 years only a few research laboratories have been able to measure it. Many of the teething troubles of the Orion SS-20 ionised calcium meter have now been surmounted, which has brought this measurement within the grasp of any hospital laboratory willing to devote to it sufficient capital, running costs, and technician time. ${ }^{1-3}$ High demand for the measurement has led a few institutions like our own, with a strong interest in renal failure and parathyroid surgery, to make the investment; in the average district general hospital the demand will be much more modest. A decision to add another financial burden to the NHS will hinge on the reliability of the available alternatives, which in ascending order of complexity are (1) uncorrected total serum calcium concentration, (2) total serum calcium with serum protein or albumin for the clinician to make an "eyeball adjustment," (3) correction of total serum calcium concentration for protein or albumin by formula, and (4) prediction of ionised serum calcium from total calcium and protein or albumin by formula or nomogram.

"Correction" of the total serum calcium concentration has been a subject of much controversy during the past two years. ${ }^{4-13}$ Pain $e t a l^{14}$ concluded that because of the large interindividual variation a tedious procedure was necessary to calculate the correction factor individually. On the other hand, the $B M \mathcal{F}^{15}$ stated: "In specialised units newer methods for ionised calcium assay may prove valuable, but for most of us the 'corrected' plasma calcium is an adequate measure of ionised calcium on almost all occasions."

We therefore compared serum ionised calcium concentrations 
as measured direct with the Orion SS-20 meter and as calculated by four indirect methods in both normal and abnormal subjects.

\section{Subjects and methods}

Serum ionised calcium, total calcium, and total protein concentrations were estimated simultaneously in 47 healthy volunteers, 33 patients with late chronic renal failure treated conservatively, 71 patients with chronic renal failure who were undergoing regular haemodialysis, and 83 patients who had received transplants. Arterial or arterialised venous blood was drawn from the patients undergoing dialysis immediately before connection to the machine. Forearm venous blood taken with minimum stasis was used in the other groups.

The serum ionised calcium concentration was measured with the Orion SS-20 ionised calcium meter, which incorporates an ionselective electrode. Our technique and its validation have been described. ${ }^{3}$ Blood was placed in $2 \mathrm{ml}$ plastic microcentrifuge tubes from which all but a minuscule bubble of air was excluded, clotted at room temperature, and stored at $4^{\circ} \mathrm{C}$ before separation and measurement in triplicate within four hours of venepuncture. The mean of three readings was used in all subsequent calculations. If more than one measurement was made in a patient on separate occasions these measurements were considered separately, since they were often repeated after a change in clinical state.

The total serum calcium concentration was measured by an automated cresolphthalein method ${ }^{16}$ and serum protein by an automated biuret method (Technicon AutoAnalyzer). Serum ionised calcium was predicted from the total serum calcium and protein concentrations by using the three formulae given below. Formula 1 is the simplified version recommended by Zeisler $^{17}$ for routine use, and formula 2 is his more accurate original formula. Formula 3 is that of McLean and Hastings. ${ }^{18}$

(1) $\left[\mathrm{Ca}^{++}\right]=[(6 \times$ total calcium $)-($ total protein $/ 3)] /($ total protein +6$)$

(2) $\left[\mathrm{Ca}^{++}\right]=\left[\left(6_{4}^{1} \times\right.\right.$ total calcium $)-($ total protein $\left.\times 3 / 8)\right] /\left(\right.$ total protein $\left.+6 \frac{1}{2}\right)$

(3) $\left[\mathrm{Ca}^{++}\right]=\frac{1}{2}[$ total calcium - total protein $-\mathrm{K}+$ $\left.\left((4 \mathrm{~K} \times \text { total calcium })+(\text { total protein }- \text { total calcium }+\mathrm{K})^{2}\right)^{\frac{1}{2}}\right]$

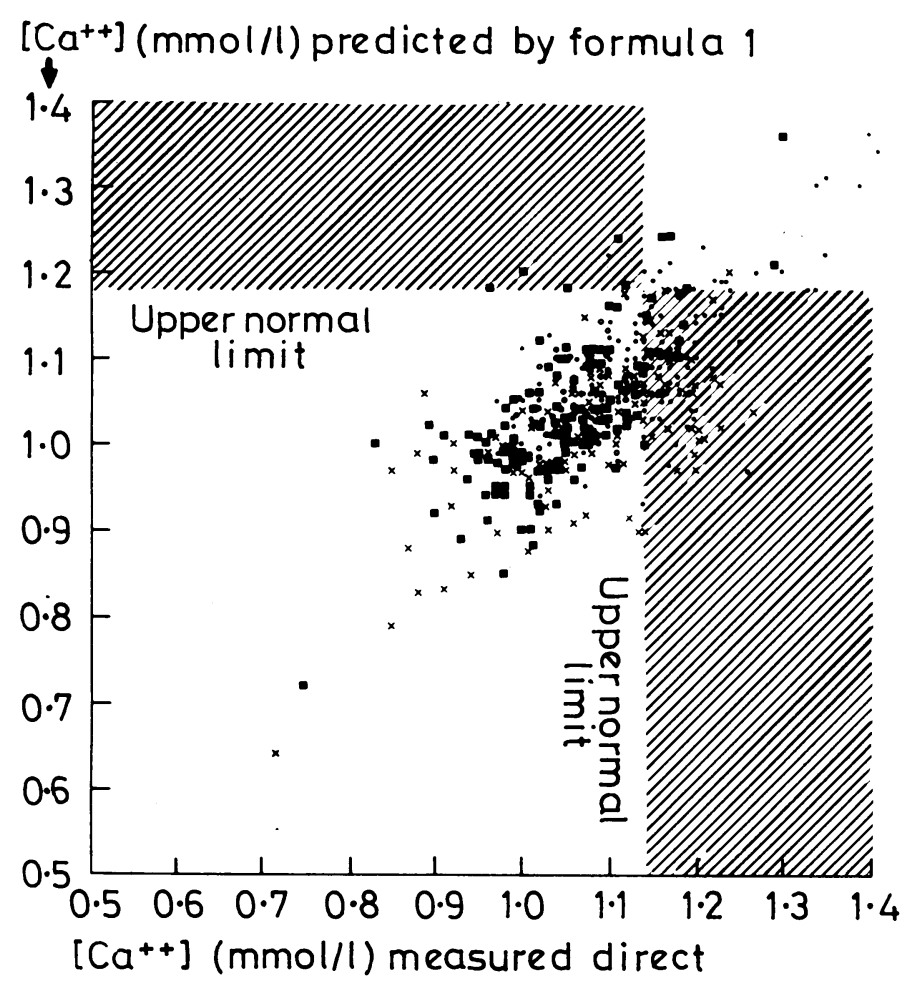

FIG 1 -Serum ionised calcium concentrations as measured direct and predicted by formula 1 . Upper limits of normal given by both methods are shown, indicating false-positive and false-negative results for patients with hypercalcaemia.

$\mathrm{O}=$ Normal subjects. $\mathrm{O}=$ Recipients of renal transplants. $\times=$ Patients with chronic renal failure treated conservatively. $\mathbf{Q}=$ Patients undergoing dialysis.

Conversion: SI to traditional units-Serum ionised calcium: $1 \mathrm{mmol} / 1 \approx 4$ $\mathrm{mg} / 100 \mathrm{ml}$.

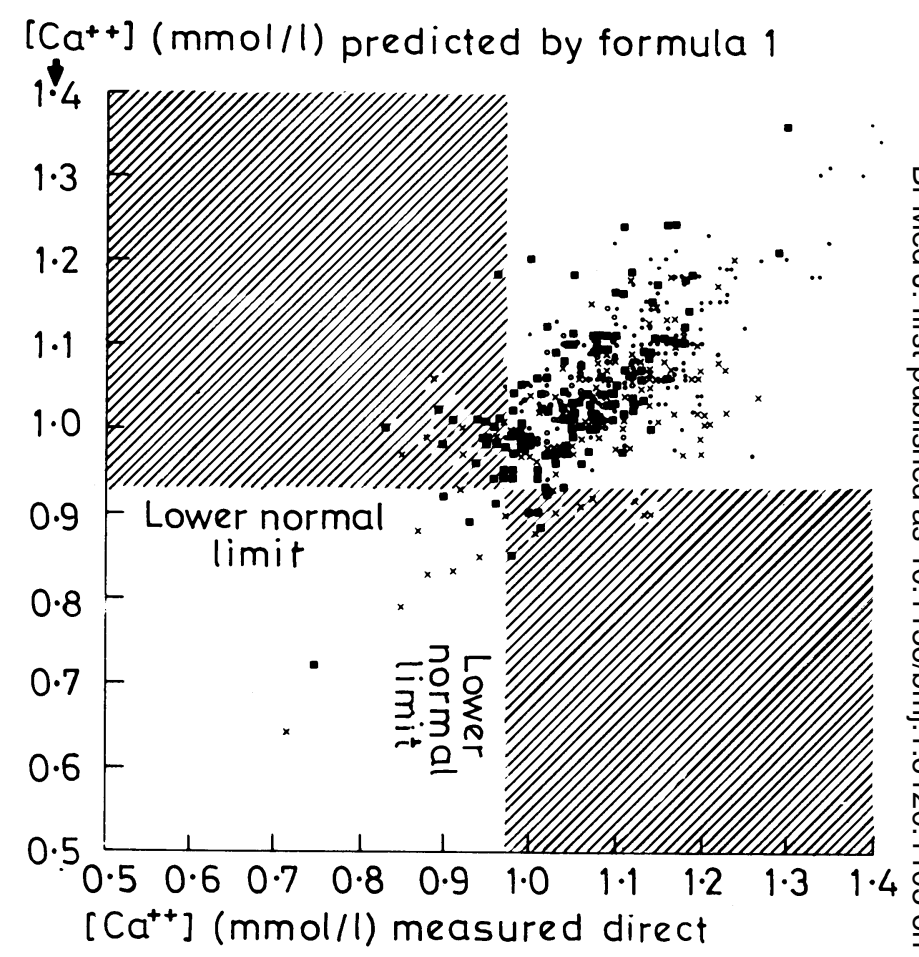

FIG 2-Serum ionised calcium concentrations measured direct and predicted by formula 1 . Lower limits of normal given by both methods are shown, indicating false-positive and false-negative results for patients with hypocalcaemia. Symbols as for fig 1.

Finally, we predicted the ionised calcium concentration from the McLean nomogram (indirect method 4), which was redrawn to six times the published size from data supplied by McLean. ${ }^{19}$ The result obtained from each prediction was compared with that obtained by direct calculation in all cases, and a paired $t$ test was carried out on the group differences.

The results of all 418 measurements were plotted for each formula and the nomogram (figs 1 and 2). The normal ranges given are the $95 \%$ confidence limits for our data on the normal subjects. From these plots we calculated the false-positive and false-negative rates for hypercalcaemia and hypocalcaemia (ionised calcium) by comparing each indirect method with the direct measurement.

\section{Results}

The table shows the mean $( \pm S D)$ results measured direct and predicted by the four indirect methods. The results in the four diagnostic categories are listed first, followed by those in patients with hypercalcaemia and hypocalcaemia (judged by direct measurement of ionised calcium) from all diagnostic categories. In the normal subjects results predicted by three of the four indirect methods were not significantly different from the measured ionised calcium concentration, but there was a wider scatter than with direct measurement. The 71 patients undergoing dialysis had a mean serum ionised calcium concentration close to normal; the results predicted by the two unsimplified formulae and the nomogram were not significantly different from the measured result. The conservatively treated patients with renal failure, some of whom were receiving vitamin-D analogues, had more variable serum ionised calcium concentrations, and all four predictions were significantly different from the measured results. This was also true for the recipients of transplants, many of whom had mild hypercalcaemia, and for the patients with hypercalcaemia and hypocalcaemia extracted from all diagnostic groups.

Figs 1 and 2 show the relation between the 418 serum ionised calcium concentrations as measurec 'irect and as predicted by formula 1. The upper limit of the normal range (fig 1 ) was $1.14 \mathrm{mmol} / 1$ (4.56 $\mathrm{mg} / 100 \mathrm{ml})$ by direct measurement and $1.18 \mathrm{mmol} / 1(4.72 \mathrm{mg} / 100 \mathrm{ml})$ by formula 1. Out of 129 measurements assessed by the Orion SS-20 as being from patients with hypercalcaemia, $98(76 \%)$ were falsely negative by formula 1 . Out of 288 measurements assessed by the machine as being from patients without hypercalcaemia, $5(1.7 \%)$ were falsely positive by formula 1 . 


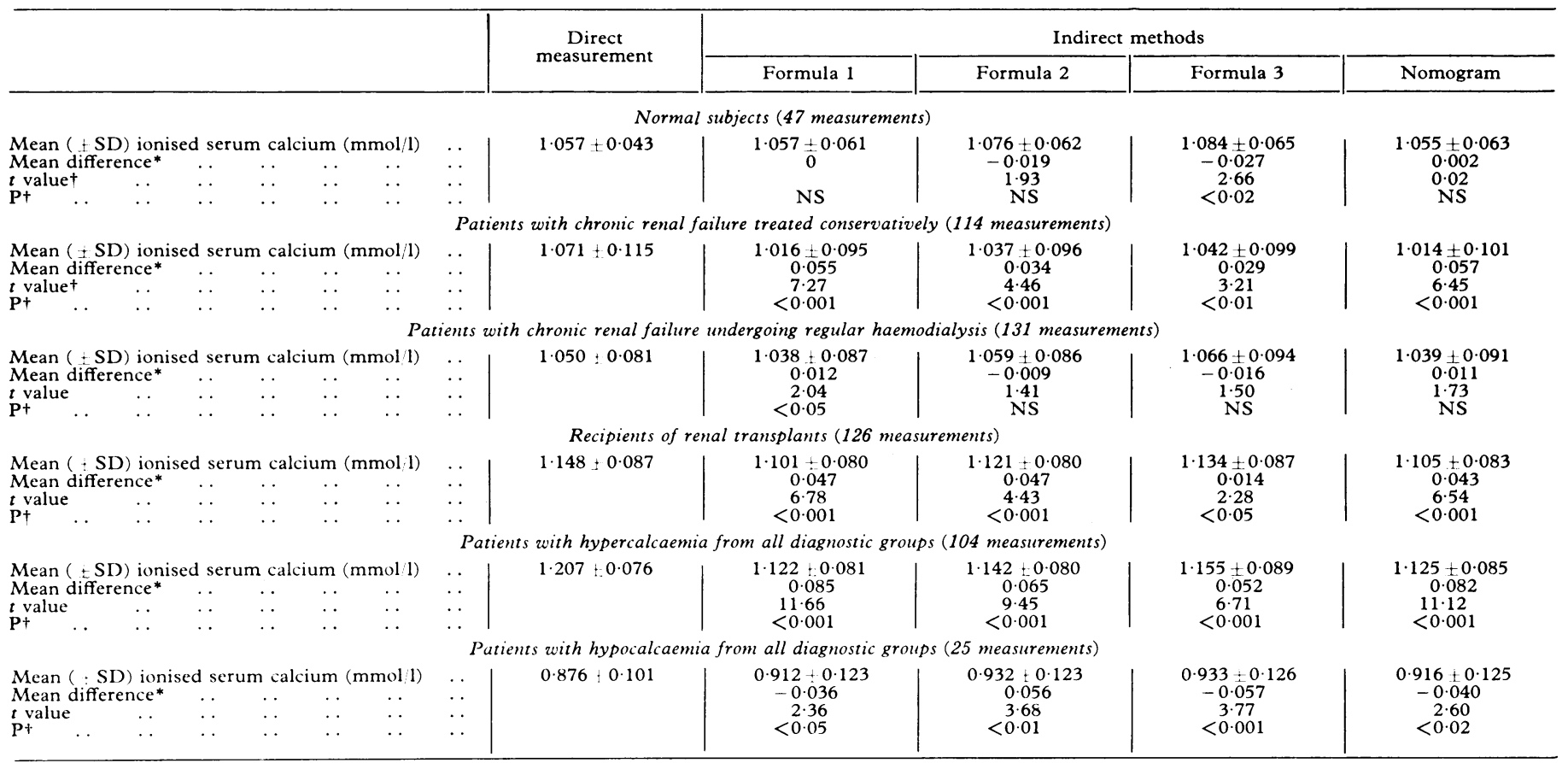

* Between mean ionised calcium by direct and indirect methods.

Concersion: SI to traditional units-Serum ionised calcium: $1 \mathrm{mmol} 1=4 \mathrm{mg} 100 \mathrm{ml}$

The lower limits of the normal range (fig 2) were $0.97 \mathrm{mmol} / \mathrm{l}$ $(3.88 \mathrm{mg} / 100 \mathrm{ml})$ by direct measurement and $0.93 \mathrm{mmol} / 1(3.72$ $\mathrm{mg} / 100 \mathrm{ml}$ ) by formula 1 . Of the 34 measurements assessed by the machine as being from patients with hypocalcaemia, $21(62 \%)$ were falsely negative by formula 1 . Of the 383 assessed by the machine as being from patients with no hypocalcaemia, $12(3.1 \%)$ were falsely positive by formula 1 .

Results were similar with the other three indirect methods. For hypercalcaemia the false-negative rates were $75.2 \%, 72.4 \%$, and $68.9 \%$ by formulae 2 and 3 and the nomogram respectively; and the false-positive rates were $1.7 \%, 2.3 \%$, and $3.1 \%$. For hypocalcaemia false-negative rates were $61 \cdot 2 \%, 66 \cdot 7 \%$, and $63 \cdot 6^{\circ}$, ; and false-positive rates $2.8 \%, 3.0 \%$, and $3.0 \%$ respectively.

\section{Discussion}

Clearly predicting the serum ionised calcium concentration from total serum calcium and protein concentrations, though satisfactory in the normal range, is of little value in patients with hypercalcaemia or hypocalcaemia. These conditions are seriously underdiagnosed when the indirect methods are used. All four indirect methods give closely similar results, so we doubt whether any further refinement of the formulae would improve prediction appreciably. Much of the error of these indirect methods is probably due to the variable binding of calcium to protein in different people, which was shown by Pain et al ${ }^{14}$ using albumin. Thus it is unlikely that the prediction of ionised calcium from total calcium and albumin concentrations would be much more accurate than the published methods, which are all based on total serum protein.

Our study was confined to patients with renal failure, in which measurements of the ionised calcium concentration are in great demand. The results cannot be extrapolated to all other diseases since protein binding is altered in uraemia. Nevertheless, our preliminary studies on 12 patients with primary hyperparathyroidism also show significant differences between the mean results obtained by direct measurement and by three of the four indirect methods (formulae 1 and 2 and the nomogram).

The "correction" of total serum calcium concentration to a standard concentration of serum protein or albumin is based on the same principles as the prediction of ionised calcium concentration. We therefore suggest that corrected serum calcium is a poor substitute for the direct measurement of serum ionised calcium. The figures clearly show that indirect estimation can lead to the serum ionised calcium concentration being overestimated by up to $10^{\circ}{ }_{0}$, which could cause delay in recognising true hypercalcaemia and thus adversely affect renal function and metastatic calcification.

SC is assistant professor at the Federal University of Pelotas, Brazil, and is supported by a grant from CAPES, Brasilia, Brazil.

We acknowledge the help of numerous colleagues engaged in the care of these patients, notably Dr P Aljama, Dr R W Elliott, Dr T G Feest, and Dr R Wilkinson.

Requests for reprints should be addressed to: Professor D N S Kerr, Department of Medicine, Royal Victoria Infirmary, Newcastle upon Tyne NE1 4LP.

\section{References}

${ }^{1}$ Madsen, S, and Ølgaard, K, Clinical Chemistry, 1977, 23, 690.

${ }^{2}$ Husdan, $\mathrm{H}$, et al, Clinical Chemistry, 1977, 23, 1777.

3 Conceicao, S C, et al, Clinica Chimica Acta. In press.

${ }^{4}$ Berry, E M, et al, British Medical fournal, 1973, 4, 640.

5 Payne, R B, et al, British Medical fournal, 1973, 4, 643.

'Sanderson, C, British Medical Fournal, 1974, 1, 245.

7 Parfitt, A M, British Medical fournal, 1974, 1, 520.

${ }^{8}$ Hodgkinson, H M, British Medical fournal, 1974, 2, 223.

${ }^{9}$ Payne, R B, et al, British Medical fournal, 1974, 2, 504.

10 Payne, R B, et al, British Medical fournal, 1974, 3, 345.

11 Payne, R B, et al, British Medical fournal, 1974, 4, 531.

12 Marshall, R W, and Nordin, B E C, British Medical fournal, 1974, 2, 729.

${ }^{13}$ Ramsay, L E, et al, British Medical fournal, 1976, 1, 219.

14 Pain, R W, et al, British Medical fournal, 1975, 4, 617.

${ }^{15}$ British Medical fournal, 1977, 1, 598.

16 Gitelman, H J, Analytical Biochemistry, 1967, 18, 521.

17 Zeisler, E B, American fournal of Clinical Pathology, 1954, 24, 588.

${ }^{18}$ McLean, F C, and Hastings, A B, Fournal of Biological Chemistry, 1935, $108,285$.

19 McLean, F C, Science, 1935, 82, 104. 